\title{
Influence of Adolescents' Smartphone Addiction on Mental and Emotional Development in West Java, Indonesia
}

\author{
Meita Dhamayanti, ${ }^{1}$ Resti Gradia Dwiwina, ${ }^{2}$ Rubiah Adawiyah ${ }^{3}$ \\ ${ }^{1}$ Department of Child Health Faculty of Medicine Universitas Padjadjaran/Dr. Hasan Sadikin General Hospital \\ Bandung, Indonesia, ${ }^{2}$ Department Biomedical Sciences, Faculty of Medicine, Universitas Padjadjaran, Indonesia, \\ ${ }^{3}$ Study Program of Undergraduate Medicine, Faculty of Medicine, Universitas Padjadjaran, Indonesia
}

\begin{abstract}
Smartphone use is widespread globally, including in Indonesia. The excessive use and ubiquity of smartphone technology raise concerns on addiction and its effects on mental and emotional development of adolescents. This study aimed to analyze the correlation between smartphone addiction and mental-emotional disorders in early adolescents aged 11-12 years old in several primary schools in Bandung City and Sumedang District. This study was performed October to December 2018. This was a cross-sectional study using convenient sampling technic with unpaired categorical data for subject selection. Subjects were assessed with the Smartphone Addiction Scale Short Version (SAS-SV) and Strength and Difficulties Questionnaire (SDQ) which were self-administered by subjects. Subjects were classified into low level and high level smartphone user groups. Data were analyzed using chi square test. Out of 206 subjects, only 178 met the inclusion criteria with $44.9 \%(n=80)$ and $55.10 \%(n=98)$ were in high- and low-level of smartphone addiction. The percentage of mental and emotional problems based on SDQ that was included in the normal, borderline, and abnormal category was 60.7, 21.9, 17.4, respectively. Those with high-level smartphone addiction had mental and emotional problems with 1.425 prevalence ratio and CI95\% 1.141-1.779. In conclusion, there is correlation between smartphone addiction on mental emotional problems of early adolescent.
\end{abstract}

Key words: Early adolescent, smartphone addiction, mental and emotional, West Java, Indonesia

\section{Pengaruh Kecanduan Gawai pada Perkembangan Mental dan Emosional Remaja di Jawa Barat, Indonesia}

\begin{abstract}
Abstrak
Pemakaian gawai sudah menyebar ke berbagai negara termasuk Indonesia. Pemakaian gawai sendiri memiliki dampak positif serta negatif. Salah satu dampak negatifyaitu mengalami kecanduan gawai sehingga mempengaruhi emosi dan perilaku dan juga dapat menurunkan produktifitas serta kualitas hidup. Tujuan penelitian ini adalah untuk menganalisis hubungan pengaruh kecanduan gawai terhadap gangguan mental emosional pada remaja awal usia 11-12 tahun. Metode penelitian menggunakan analitik pontong lintang dari beberapa Sekolah Dasar Kota Bandung dan Kabupaten Sumedang pada Oktober sampai Desember 2018. Subjek dipilih dengan metode convenient data kategori tidak berpasangan Subjek mengisi kuesioner yang berisi data sosiodemografi, Strength Difficulties Questionnaire (SDQ) dan Smartphone Addiction Scale-Short Version (SAS-SV). Subjek dibagi 2 kelompok tingkat kecanduan rendah dan tinggi. Data yang diperoleh dianalisis dengan menggunakan uji chi square. Dari 206 sebanyak 178 memenuhi kriteria. Subjek dengan tingkat kecanduan gawai tinggi sebanyak 80 $(44,9 \%)$ dan rendah 98 (55,1\%). Persentase gangguan mental emosional normal $(60,7)$, borderline $(21,9)$ dan abnormal $(17,4)$. sebanyak 31 responden atau 17,4\%. Terdapat hubungan bermakna Tingkat kecanduan gawai yang tinggi dan masalah mental emosi (rasio prevalens 1,45 (IK 1,141-1,779). Simpulan, terdapat hubungan tingkat kecanduan gawai dan masalah mental emosio remaja awal usia 11-12 tahun.
\end{abstract}

Kata kunci: Gawai, mental emosional, remaja awal

Corresponding Author: Meita Dhamayanti, Department of Child Health Faculty of Medicine Universitas Padjadjaran/ Dr. Hasan Sadikin General Hospital Bandung, Jalan Pasteur No. 38 Bandung, 40161, West Java, Indonesia, Email: meita. dhamayanti@unpad.ac.id 


\section{Introduction}

Smartphones are an instrument that has a particular function, designed to be practical and sufficiently advanced to be used in daily activities. Smartphone usage has become widespread globally. Indonesia is the $5^{\text {th }}$ highest smartphone user in the world that takes $54 \%$ of total screen time. ${ }^{1}$ Smartphone use in Indonesia has risen sharply since 2012; $91 \%$ of Indonesian have a mobile phone, with all age groups using smartphones from preschoolers to parents. ${ }^{2}$ Pre-schoolers are able to operate the smartphones with or without parental supervision. Smartphones can be used for a variety of purposes ranging from playing games, listening to music, watching videos, and accessing information and social media via internet. Previous studies indicated that the majority of smartphone uses were related to entertainment purposes (such as video games), although there were other uses for smartphones, such as study aid and for praying. ${ }^{3}$ The majority of smartphones are used to access the internet. Internet users in Indonesia in 2016 reach 132.7 million users from 256.7 million Indonesians, which approximately $51.7 \%$ of all Indonesians have access to internet; while in 2017, internet users reach 143.26, which approximately $54.7 \%$ of the total population of Indonesia. The majority of internet users live in Java island (86.3 million users or $65 \%$ of the total population of Indonesia). The majority of internet users are children and adolescents consisting of $79.5 \%$ of all internet users in Indonesia, particularly in 5-12 year old age group. Internet users in urban area are more than semi-urban area and rural area. ${ }^{4}$

Smartphones may be used as tools to aid learning and as entertainment media for children. Although there are many positive impacts of gadgets that facilitate teenagers, excessive usage is always not a good thing. Excessive smartphone usage may lead to dry eyes due to inadequate blinking and may significantly decrease social interactions of the children. Social interaction is defined as social relationship between individuals and is one of many aspects of social life. Through social interactions, children will learn how to live in a society and to know better about themselves. ${ }^{3}$ Smartphone addiction may affect emotional and behavioral development, and may also adversely affect productivity and quality of life. Previous studies have shown correlation between severity of smartphone addiction and emotional and behavioral disorders. ${ }^{5,6}$

According to World Health Organization (WHO), there are $20 \%$ children and adolescents suffering from mental disorders. The prevalence of mental disorders in Europe and United states are $16.3 \%, 17.8 \%, 16 \%$, and $18.4 \%$ for 8 years old, 13 years old, 18 years old, and 25 years old, respectively. ${ }^{7}$ There are approximately $12.5 \%$ of children aged 6-12 years old with emotional and behavioral disorders in Singapore . $^{8}$

Mental and emotional disorders are a form of psychological distress. According to the 2013 Indonesia Basic Health Research (IBHR), the prevalence of mental and emotional disorders in Indonesia is 6\%, with the highest prevalence rate found in Central Sulawesi, South Sulawesi, West Java , Yogyakarta and East Nusa Tenggara. The lowest prevalence of mental and emotional disorders in Indonesia was found in Lampung . The prevalence rate of mental and emotional disorders in West Java is higher compared to the national average( $9.3 \%$ vs $6 \%) .{ }^{9}$

Psychosocial stressors may act as one of many triggers to mental and emotional disorders. Cognitive development of children may be adversely affected by such disorders, leading children to view their environs more negatively and tend to have a more negative self -perception. Parents may also complain about lack of social interaction with their child, limiting the communication between them. Children aged 9-13 years old are still significantly affected by their interactions with their parents. Children aged 12 years old have the highest prevalence of emotional disturbance. ${ }^{8}$

According to prevalence data from the 2007 and 2013 IBHR, there are differences of prevalence rate according to the location. According to the 2007 IBHR, rural areas have higher prevalence of mental and emotional disorders, while according to the 2013 IBHR, urban areas have higher prevalence of mental emotional disorders compared to the rural areas. ${ }^{9}$ A study by Firmansyah, et al., 2018 found significant differences in prevalence of mental and emotional disorders between urban and semi-urban areas. Urban areas have significantly higher prevalence of mental and emotional disorders compared to semi-urban areas. The patterns are corresponding to data from the 2013 IBHR, with the aforementioned study found higher rates of mental and emotional disorders in urban areas compared to rural areas. Smartphone use may be one of many factors that may correlate with higher rates of mental disorders in urban areas. ${ }^{10}$ 
The aim of this study was to analyze the correlation between smartphones on mental and emotional development of early adolescents. This study may improve the knowledge regarding smartphone addiction and its relationship on mental disorders on early adolescents. The information acquired from this study may aid educational institutions regarding students with mental and emotional problems. Future studies may be required to consolidate the findings of this study, of which this study may provide the groundwork necessary for future study of the same topic.

\section{Methods}

The cross-sectional study with unpaired categorical data was conducted from October to December 2018. The selected study population of this study was early adolescents aged 1112 years in primary schools of Bandung City and Sumedang District. The primary schools selected for this study was Sekolah Dasar Negeri (SDN) Cibesi, SDN Hegarmanah, SDN Jatinangor, SDN Cikuda, and SDN Sayang in Sumedang District, and SDN 048 Sirnamanah and SDN 018 Sukagalih in Bandung city. The sampling method used convenient sampling technique and the minimum sample size for this study was 178 subjects. The inclusion criteria in this study were students in primary school, aged 11-12 years and smartphone users. The exclusion criteria in this study were ill students and students who were absent from school. The instruments were informed consent, sociodemographic data, Smartphone Addiction Scale Short Version (SASSV) questionnaire, and Strength and Difficulties Questionnaire (SDQ).

The severity of smartphone addiction was assessed using SAS-SV,11 which was modified to Indonesian version. ${ }^{12}$ Mental and emotional disturbances were assessed with SDQ ${ }^{13}$ which was modified to Indonesian version as well. ${ }^{8}$ Mental emotional problems were measured using self-reported SDQ, which consisted of 25 attributes in questions, assessing total difficulties (emotional symptoms, conduct problems, hyperactivity/inattention, peer relationship problems), and assessing total strength or prosocial behavior. The SDQ was categorized as normal, borderline, and abnormal. SAS-SV consists of 10 attributes, which had 6 factors such as affect of daily activity, positive anticipate, withdrawal effect, cyberspace relationship, excessive and tolerance. The SAS-SV was categorized into high and low.

The analyzed variables were distribution of patient characteristics according to gender, age, socioeconomic status, frequency of smartphone use, family status, smoking or no smoking status, duration of smartphone use and purposes of smartphone use. The sociodemographic results were presented in Table 1 . Frequencies of mental and emotional disturbances were presented in Table 2. Analysis of effects of smartphone use on mental and emotional disturbances were presented in Table 3 for Bandung City and in Table 4 for Sumedang District. Analytical statistics for correlation between smartphone use and mental and emotional disturbances were presented in Table 4. Data analysis wasperformed using IBM ${ }^{\circledR}$ Statistical Program for Social Science (SPSS) ${ }^{\circledR}$ version 25.

Before the study was conducted, ethical clearance had been received from Ethical Committee of Health Research Faculty of Medicine Universitas Padjadjaran No. 0118091273.

\section{Results}

Out of 206 students, there were 178 students who had inclusion criteria. The students were primary school students in Bandung City and Sumedang District.

According to the study results above (Table 1), there were 91 female students $(51.1 \%)$ more than male students. There were 105 students $(59 \%)$ aged 11 years with mean \pm Standard Deviation (SD) of $11.41 \pm 0.493$. According to parental income, there were most in low income, spesificly in Sumedang District. The majority of students still had two parents in their family (174 students, 97.8\%) than single parent. According to student smoking status, there were 17 smokers (9.6\%), majority in Sumedang District (11 students, 12.4\%). Based on smartphone use duration, most of the students were categorized as low (80 students, 44.9\%). According to smartphone use intensity, the students were mostly in high categories (64 students, $36.0 \%$ ), specifically in Bandung City. The students used smartphone mostly to communicate and send text message (102 students, 57.3\%).

The current study found 31 students (17.4\%) with abnormal functioning. Students in Sumedang were more frequently abnormal in functioning compared to students in Bandung. Smartphone addiction assessment using SAS-SV consisted of 80 students (44.9\%) with high SAS$\mathrm{SV}$. Students in Bandung were more frequently 
M. Dhamayanti, et al: Influence of Adolescents' Smartphone Addiction on Mental and Emotional Development in West Java,, Indonesia

Table1 Sociodemographic Characteristics of Study Subjects

\begin{tabular}{|c|c|c|c|}
\hline Variable & $\begin{array}{c}\text { Sumedang } \\
n=89 \\
n(\%) \\
\end{array}$ & $\begin{array}{c}\text { Bandung } \\
n=89 \\
n(\%) \\
\end{array}$ & $\begin{array}{c}\text { Total } \\
n=178 \\
n(\%)\end{array}$ \\
\hline $\begin{array}{l}\text { Gender: } \\
\text { Male } \\
\text { Female }\end{array}$ & $\begin{array}{l}41(46.1) \\
48(53.9)\end{array}$ & $\begin{array}{l}46(51.7) \\
43(48.3)\end{array}$ & $\begin{array}{l}87(48.9) \\
91(51.1)\end{array}$ \\
\hline $\begin{array}{c}\text { Age (years): } \\
\begin{array}{c}11 \\
12\end{array}\end{array}$ & $\begin{array}{l}45(50.6) \\
44(49.4)\end{array}$ & $\begin{array}{l}60(67.4) \\
29(32.6)\end{array}$ & $\begin{array}{c}105(59.0) \\
73(41.0)\end{array}$ \\
\hline $\begin{array}{l}\text { Parental income/month: } \\
\text { IDR }<1,5 \text { million } \\
\text { IDR } 1.5-2.5 \text { million } \\
\text { IDR } 2.5-3.5 \text { million } \\
\text { IDR }>3.5 \text { million }\end{array}$ & $\begin{array}{l}42(47.2) \\
10(11.2) \\
22(24.7) \\
15(16.9)\end{array}$ & $\begin{array}{l}37(41.6) \\
16(18.0) \\
12(13.5) \\
24(27.0)\end{array}$ & $\begin{array}{l}79(44.4) \\
26(14.6) \\
34(19.1) \\
39(21.9)\end{array}$ \\
\hline $\begin{array}{l}\text { Parental status: } \\
\text { Two parents } \\
\text { Single parent }\end{array}$ & $\begin{array}{c}87(97.8) \\
2(2.2)\end{array}$ & $\begin{array}{c}87(97.8) \\
2(2.2)\end{array}$ & $\begin{array}{c}174(97.8) \\
4(2.2)\end{array}$ \\
\hline $\begin{array}{l}\text { Smoking: } \\
\text { Yes } \\
\text { No }\end{array}$ & $\begin{array}{l}11(12.4) \\
78(87.6)\end{array}$ & $\begin{array}{c}6(6.7) \\
83(93.3)\end{array}$ & $\begin{array}{c}17(9.6) \\
161(90.4)\end{array}$ \\
\hline $\begin{array}{l}\text { Level of smartphone use } \\
\text { Duration (minutes): } \\
\text { 75-120 (high) } \\
\text { 40-60 (moderate) } \\
\text { 5-30 (low) } \\
\text { Intensity: } \\
>3 \times \text { /day (high) } \\
2-3 \text { x/day (moderate) } \\
<2 \times \text { day (low) }\end{array}$ & $\begin{array}{l}32(36.0) \\
24(27.0) \\
33(37.1)\end{array}$ & $\begin{array}{l}50(56.2) \\
19(21.3) \\
20(22.5) \\
32(36.0) \\
33(37.1) \\
24(27.0)\end{array}$ & $\begin{array}{l}5128.7 \\
4726.4 \\
8044.9 \\
64(36.0) \\
57(32.0) \\
57(32.0)\end{array}$ \\
\hline $\begin{array}{l}\text { Goals of smartphone use: } \\
\text { Text messaging and communication } \\
\text { Entertainment } \\
\text { Study } \\
\text { Playing games } \\
\text { Telephone } \\
\text { Others }\end{array}$ & $\begin{array}{l}56(62.9) \\
33(37.1) \\
44(49.4) \\
34(38.2) \\
20(22.5) \\
14(15.7)\end{array}$ & $\begin{array}{l}46(51.7) \\
44(49.4) \\
56(62.9) \\
46(51.7) \\
37(41.6) \\
24(27.0)\end{array}$ & $\begin{array}{c}102(57.3) \\
77(43.3) \\
100(56.2) \\
80(44.9) \\
57(32.0) \\
38(21.3)\end{array}$ \\
\hline
\end{tabular}

Table 2 Frequencies of Mentalemotional Disorders and SAS-SV

\begin{tabular}{lccc}
\hline \multicolumn{1}{c}{ Characteristics } & Sumedang & Bandung & $\begin{array}{c}\text { Total } \\
\mathrm{n}=178 \\
\mathrm{n}(\%)\end{array}$ \\
\cline { 2 - 3 } & $\begin{array}{c}\mathrm{n}=89 \\
\mathrm{n}(\%)\end{array}$ & $\begin{array}{c}\mathrm{n}=89 \\
\mathrm{n}(\%)\end{array}$ & $\begin{array}{c}108(61) \\
\text { Mental Emotional: }\end{array}$ \\
$\begin{array}{l}\text { Normal } \\
\text { Borderline }\end{array}$ & $50(56)$ & $58(65)$ & $39(22)$ \\
Abnormal & $23(26)$ & $16(18)$ & $31(17)$ \\
SAS-SV: & $16(18)$ & $15(17)$ & \\
Low & & & $98(55)$ \\
High & $56(63)$ & $47(53)$ & $80(45)$ \\
\hline
\end{tabular}


Table 3 Effect of Smartphones on Mental-Emotional Disorders in Bandung City

\begin{tabular}{ccccc}
\hline \multirow{2}{*}{$\begin{array}{c}\text { Effect of } \\
\text { Smartphones }\end{array}$} & \multicolumn{3}{c}{ Mental Emotional Disorders } & \multirow{2}{*}{ PR } \\
\cline { 2 - 4 } & $\begin{array}{c}\text { Normal } \\
\mathbf{n}(\%)\end{array}$ & $\begin{array}{c}\text { Borderline } \\
\mathbf{n}(\%)\end{array}$ & $\begin{array}{c}\text { Abnormal } \\
\mathbf{n}(\%)\end{array}$ & $\mathbf{( 9 5 \% \mathbf { ~ C I } )}$ \\
\hline Low & $36(86)$ & $5(12)$ & $1(2)$ & 1.592 \\
High & $22(47)$ & $11(23)$ & $14(30)$ & $(1.220-2.077)$ \\
TOTAL & $58(65)$ & $16(18)$ & $15(17)$ & \\
\hline
\end{tabular}

$\mathrm{PR}=$ prevalence ratio; $\mathrm{CI}=$ confidence interval; $\mathrm{p}<0.05$ with chi-square test

Table 4 Effect of Smartphones on Mental Emotional Disorders in Sumedang Regency

\begin{tabular}{|c|c|c|c|c|}
\hline \multirow{2}{*}{$\begin{array}{c}\text { Effect of } \\
\text { Smartphones }\end{array}$} & \multicolumn{3}{|c|}{ Mental Emotional Disorders } & \multirow{2}{*}{$\begin{array}{c}\text { PR } \\
(95 \% \mathrm{CI})\end{array}$} \\
\hline & $\begin{array}{c}\text { Normal } \\
\text { n (\%) }\end{array}$ & $\begin{array}{c}\text { Borderline } \\
\text { n (\%) }\end{array}$ & $\begin{array}{c}\text { Abnormal } \\
\text { n (\%) }\end{array}$ & \\
\hline Low & $38(68)$ & $9(16)$ & $9(16)$ & \multirow{3}{*}{$\begin{array}{c}1.280 \\
(0.884-1.854)\end{array}$} \\
\hline High & $12(37)$ & $14(42)$ & $7(22)$ & \\
\hline TOTAL & $50(56)$ & $23(26)$ & $16(18)$ & \\
\hline
\end{tabular}

$\mathrm{PR}=$ prevalence ratio; $\mathrm{CI}=$ confidence interval; $\mathrm{p}=0.008$ with chi-square test

highly addicted compared to students in Sumedang (Table 2).

According to the study above (Table 3-5), there were 21 students (26\%) who had mental emotional disorders with smartphone addiction; 14 students (30\%) in Bandung and 7 students (21\%) in Sumedang. Through bivariate analysis using chi-square test, the study found that smartphone had a significant affect with total difficulties particularly regarding mental emotional disorders as shown in Table 5 for early adolescents $(\mathrm{p}<0.05)$ with PR (normal/ abnormal) and 95\% confidence interval (CI) of 1.592 (1.220-2.077); 1.280 (0.884-1.854); 1.425 (1.141-1.779), respectively. Moreover, using Chi Square test, the study found that smartphone did not significantly affect prosocial behaviour $(\mathrm{p}=0.895)$

\begin{abstract}
Discussion
Today's generation $\mathrm{Z}$ adolescents (born from 1995 to the present) are millennials, internet generation, or digital natives. This generation tends to have some problems if they are separated to their gadgets in this era of globalization. They always want to get short, up-to-date, and realtime information with picture attached. ${ }^{14}$

In previous study, it was found that smartphone addiction is significantly correlated with mental emotional disorder. The result is in line with a study by Ahmad Ramadhan (2017) which also found that smartphone addiction significantly correlated with emotional and behavioral disturbances of adolescents. ${ }^{12}$ The other study also concluded that internet user addiction is an association among psychiatric symptoms such as somatization, sensitivity,
\end{abstract}

Table 5 Effect of Smartphones on Mental Emotional Disorders in Bandung City and Sumedang Regency

\begin{tabular}{|c|c|c|c|c|}
\hline \multirow{2}{*}{$\begin{array}{c}\text { Effect of } \\
\text { Smartphones }\end{array}$} & \multicolumn{3}{|c|}{ Mental Emotional Disorders } & \multirow{2}{*}{$\begin{array}{c}\text { PR } \\
(95 \% \mathrm{CI})\end{array}$} \\
\hline & $\begin{array}{c}\text { Normal } \\
\text { n (\%) }\end{array}$ & $\begin{array}{c}\text { Borderline } \\
\text { n (\%) }\end{array}$ & $\begin{array}{c}\text { Abnormal } \\
\text { n (\%) }\end{array}$ & \\
\hline Low & $74(76)$ & $14(14)$ & $10(10)$ & \multirow{3}{*}{$\begin{array}{c}1.425 \\
(1.141-1.779)\end{array}$} \\
\hline High & $34(43)$ & $25(31)$ & $21(26)$ & \\
\hline TOTAL & $108(61)$ & $39(22)$ & $31(17)$ & \\
\hline
\end{tabular}

$\mathrm{PR}=$ prevalence ratio; $\mathrm{CI}=$ confidence interval; $\mathrm{p}<0.05$ with chi-square test 
depression, anxiety, aggression, phobias, and psychosis. ${ }^{6}$

This current study also found that $44.9 \%$ of students had high-level smartphone addiction. In a study in India, it was found that $33.3 \%$ out of total $87 \%$ who are smartphone user are in highlevel addiction as well. ${ }^{15}$ Hence, this finding is corresponding to other studies that smartphone usage may carry disadvantage effect, with one of the most significant drawbacks of excessive smartphone usage that is being addicted to smartphone and decrease productivity and quality of life. ${ }^{3,16}$ Furthermore, the study is similar to a study conducted by Arifin and Rahmadi ${ }^{17}$ that concluding that severe smartphone addiction is correlated with academic achivements.

The current study found that Sumedang District had higher rates of mental and emotional disorder compared to rates in Bandung City. However, this study contradicted the previous data form the 2013 IBHR and a study conducted by Rizqy Firmansyah ${ }^{9}$ concluding that rates of mental emotional disorders are higher in urban areas compared to rates in semiurban and rural areas. ${ }^{10}$ The contradiction may be caused by different population and age categories. Thus, it is suggested to obtain in depth detail age categories and large population.

The students in Bandung City are highly addicted to smartphone compared to students in Sumedang District. The study is in line with APJII 2018 stating that internet users are mostly in urban areas compared to internet users in semiurban and rural areas. ${ }^{4}$ In this current study, it was found that smartphones were used for sending text messages, studying, and playing video games. Previous studies found that the majority of pre-schoolers use smartphones, tablets, iPad, or laptops to play video games ${ }^{3} . \mathrm{In}$ addition, WHO concluded that gaming disorder is defined in the $11^{\text {th }}$ Revision of the International Classification of Disease (ICD-11). ${ }^{18}$ The results are also in line with previous study conducted by Sundus ${ }^{19}$ in 2017, in which the majority of children use smartphones to communicate with parents, study, play games, and others.

In this study, duration of smartphone use was more prevalent among low categories and the intensity was more prevalent among high categories. It was well established that the low duration use of smartphone may have possibility of having high intensity. The study was also supported by UNICEF 2017 that non-use or excessive use of smartphone has a small negative impact and is not as relevant as other factors known to be important to children's mental well- being. ${ }^{20}$

The current study found that the majority of students who smoke are in Sumedang District. Another study found that adolescents with mental emotional problems generally started smoking at a younger age and this makes tobacco control an important issue to be addressed in young people as the number of cigarettes smoked per day will likely be higher when the habit becomes addition. ${ }^{13}$ It will be interesting to obtain in depth detailed on how smoking addiction relates to smartphone addiction.

A limitation of this study is that this crosssectional study design used self-reported data and 178 sample sizes. The study may provide additional information in researching the same topic, perhaps, in other age groups, and in observing other risk factors associated with mental-emotional disorders in urban, semiurban, and rural areas with other designs and large sample sizes.

There are correlations between smartphone addictions associated with mental emotional disorders in 11-12 year old adolescents. Further studies are required to determine whether these are precursors or sequelae.

\section{References}

1. Brown M. AdReaction: marketing in multiscreen world. 2014 [cited 2018 November 8]. Available from : https://www. millwardbrown.com/adreaction/2014/ report/Millward Brown_AdReaction-2014_ Global

2. Manumpil B, Ismanto Y, Onibala F . Hubungan penggunaan gadget dengan tingkat prestasi siswa di SMA negeri 9 Manado. Ejournal Keperawatan (e-Kep). 2015;3(2):1-6.

3. Sari TP, Mitsalia AA. Pengaruh penggunaan gadget terhadap personal sosial anak usia pra sekolah di TKIT Al Mukmin. PROFESI. 2016;13(2):72-8.

4. Survei APJII: Penetrasi internet di Indonesia capai 143 juta jiwa. Buletin APJII 2018 [cited 2018 July 8]. Available from: https://apjii.orid/downfile/file/ BULETINAPJIIEDISI22Maret2018.pdf

5. Purnomo A. Hubungan antara kecanduan gadget (mobile phone) dengan empati pada mahasiswa. [thesis] Yogyakarta: Universitas Islam Negeri Sunan Kalijaga; 2015.

6. Alavi SS, Maracy MR, Jannatifard F, Eslami M. The effect of psychiatric symptoms on the internet addiction disorder in Isfahan's 
University students. J Res Med Sci. 2011; 16(6):793-800.

7. Remschmidt HDMB. Mental health care for childrenandadolescentsworldwide: areview. World Psychiatry. 2005;4(3):147-153.

8. Wiguna T, Samuel P, Manengkei K, Pamela C, Rheza AM, Hapsari WA. Masalah emosi dan perilaku pada anak dan remaja di Poliklinik Jiwa Anak dan Remaja RSUPN dr. Ciptomangunkusumo (RSCM), Jakarta. Sari Pediatri. 2010;12(4):270-7.

9. Badan Penelitian dan Pengembangan Kesehatan Kementerian Kesehatan Republik Indonesia. Jakarta: Kemenkes RI; 2013.

10. Dhamayanti M, Peryoga SU, Firmansyah MR. Emotional mental problems among adolescents: urban and semi-urban settings. Althea Medical Journal. 2018;5(2):77-81.

11. Kwon M, Kim D-J, Cho H, Yang S. The smartphone addiction scale: development and validation of a short version for adolescents. PLoS ONE. 2013;8(12):e83558.

12. Asif AR, Rahmadi FA. Hubungan tingkat kecanduan gadget dengan gangguan emosi dan perilaku remaja usia 11-12 tahun. Jurnal Kedokteran Diponegoro. 2017;6(2):148-57.

13. Lawrence D, Mitrou F, Sawyer MG, Zubrick SR. Smoking status, mental disorders and emotional and behavioural problems in young people: child and adolescent component of the national survey of mental
Health and wellbeing. Aust N Z J Psychiatry. 2010;44(9):805-14.

14. Törocsik M, Szucs K, Kehl D. How generations think: research on generation z. Acta Univ Sapientiae Communicatio. 2014;1:23-45.

15. Soni R, Upadhyay R, Jain M. Prevalence of smartphone addiction, sleep quality and associated behaviour problems in adolescents. Int J Res Med Sci.2017;5(2):5159.

16. Radliya R, Apriliya S, Zakiyyah TR. Pengaruh penggunaan gawai terhadap perkembangan sosial emosional anak usia dini. Jurnal PAUD Agapedia. 2017;1(1):1-12.

17. Arifin LA, Rahmadi FA. Hubungan tingkat kecanduan gadget dengan prestasi belajar siswa usia 10-11 tahun. JKD. 2017;6(2):72836.

18. WHO. Gaming disorder. 2018 [cited 2018 July 23]. Available from: http://www.who. int/features/qa/gaming-disorder/en/

19. Sundus M. The impact of using gadgets on children. J Depress Anxiety. 2017;7(1):1-3.

20. Kardefelt-Winther D. How does the time children spend using digital technology impact their mental well-being, social relationships and physical activity? an evidence-focused literature review. Innocenti Discussion Paper; 2017-02; Innocenti, Italy. Florence: UNICEF; 2017. 